\title{
Residents-as-teachers across graduate medical education - expanding into the undergraduate medical curriculum
}

This article was published in the following Dove Press journal:

Advances in Medical Education and Practice

10 July 2017

Number of times this article has been viewed

\section{Anita Ghosh \\ Vidushi Pradhan}

Faculty of Medicine, Imperial College London, Kensington, London, UK
Correspondence: Anita Ghosh Faculty of Medicine, Imperial College London, Kensington, London SW7 2AZ, UK

Email ag3212@ic.ac.uk

\section{Dear editor}

We read with great interest the article by Al Achkar et al highlighting the importance of residents-as-teachers (RaT) programs. ${ }^{1}$ The increasing use of RaT instruction resonated with us from a medical student perspective, as a program that should be adapted and implemented as early as medical school to allow students to develop key teaching skills as well as enhance their own learning. The importance of teaching has been recognized by the UK General Medical Council (GMC) for many years; however, it still only forms a small part of the current undergraduate curriculum with few medical schools in the UK integrating structured formal training. ${ }^{2}$

At Imperial College School of Medicine, a mandatory week-long teaching skills course takes place during our specialty year in which we are taught about different teaching styles as proposed by Honey and Mumford as well as experiential learning. ${ }^{3}$ We learn the importance of feedback and how adapting our teaching methods to the level of our audience is paramount. Assessment takes place at the end of the course in the form of a teaching session organized by groups of students, wherein we are encouraged to avoid didactic learning and incorporate interaction, role-play and a hands-on approach. We are provided with feedback on our teaching styles which can also be used in future portfolios. Zijdenbos et $\mathrm{al}^{4}$ further highlight the success of such courses as well as providing a template for other medical schools to follow.

The article highlights that one of the primary reasons for not providing RaT was a lack of time, energy and expertise. ${ }^{1}$ Introducing a parallel program during medical school overcomes this hurdle as dedicated faculty members with extensive teaching experience are ideally placed to organize and deliver a successful course with ease. This can be of great benefit to all future doctors by equipping them with a teaching framework prior to starting their clinical post. Another reason highlighted to stop RaT programs was that they were supposedly undesired. Perceptions such as "they are already aware of teaching students" are not uncommon as this was shared amongst many of our peers. ${ }^{1}$ However, the consensus amongst students after completing the course was that it highlighted the skill and training required to deliver good medical teaching, which could improve the uptake of future clinical RaT programs. Additionally, gathering detailed feedback from students ensures that the course remains sustainable and useful for future years.

Being trained to teach different aspects of medicine to our peers, at an undergraduate level, is an invaluable tool that aids learning, nurtures early acquisition of leadership skills and eases the transition into a clinical role in which teaching our juniors will be 
a regular occurrence. From our positive experience of the teaching skills course at Imperial College, we strongly feel that in line with increased RaT instruction across specialties, formal teaching training should be implemented in all medical schools to enhance the education of medical students and equip them with much-needed teaching skills for the future.

\section{Disclosure}

The authors report no conflicts of interest in this communication.

\section{References}

1. Al Achkar M, Hanaeuer M, Morrison EH, Davies MK, Oh RC. Changing trends in residents-as-teachers across graduate medical education. $A d v$ Med Educ Pract. 2017;8:299-306.

2. Shariq O, Alexopoulos AS, Razik F, Currie J, Salooja N. Teaching skills training for medical students. Clin Teach. 2013;10(3): 146-150.

3. Honey P, Mumford A. The Manual of Learning Styles. Maidenhead: Peter Honey; 1986.

4. Zijdenbos I, Fick T, ten Cate O. How we offer all medical students training in basic teaching skills. Med Teach. 2011;33(1):24-26.

Dove Medical Press encourages responsible, free and frank academic debate. The content of the International Medical Case Reports Journal 'Editorial' section does not necessarily represent the views of Dove Medical Press, its officers, agents, employees, related entities or the International Medical Case Reports Journal editors. While all reasonable steps have been taken to confirm the content of each Editorial, Dove Medical Press accepts no liability in respect of the content of any Editorial, nor is it responsible for the content and accuracy of any Editorial.

\section{Publish your work in this journal}

Advances in Medical Education and Practice is an international, peerreviewed, open access journal that aims to present and publish research on Medical Education covering medical, dental, nursing and allied health care professional education. The journal covers undergraduate education, postgraduate training and continuing medical education including emerging trends and innovative models linking education, research, and health care services. The manuscript management system is completely online and includes a very quick and fair peer-review system. Visit http://www.dovepress.com/testimonials.php to read real quotes from published authors.

Submit your manuscript here: http://www.dovepress.com/advances-in-medical-education-and-practice-journal 